\title{
Peace as a Minor, Grounded Utopia: On Prefigurative and Testimonial Pacifism
}

\author{
Mathias Thaler
}

\begin{abstract}
A common complaint about pacifism holds that it is utopian, in a pejorative sense. The worry can take various forms and directions, but when it is couched in terms of just war theory it usually includes accusations of pacifism's immorality, inconsistency and impracticality. Contemporary defenders of pacifism have responded to this complaint by delineating a highly sophisticated, empirically informed account of pacifism that foregrounds its real-world effectiveness. This article takes a different route to vindicating pacifism via a more nuanced picture of what is specifically utopian about it. I propose that peace, in at least some of its guises, can be described as a minor, grounded utopia; it is a desire for an alternative future without war and violence, whose pursuit blurs the boundaries between thought and action. Reconstructing both prefiguration and testimony as practical modes of this kind of pacifism, I maintain that minor, grounded utopias are sites rife with conflict and contestation.
\end{abstract}

\section{Is Pacifism Utopian?}

$\bigwedge$ common and long-standing complaint about pacifism holds that it is utopian, in a pejorative sense. Pacifists are frequently derided as lofty dreamers, oblivious to the harsh realities of an evil, brutal world.

Mathias Thaler (1) is a Senior Lecturer in Political Theory at the University of Edinburgh (mathias.thaler@ed.ac.uk). His main research interest is in contemporary political theory. Thaler's recent publications have appeared in the British Journal of Political Science, Constellations, Political Studies, Political Theory, and Review of Politics. He is the author of Naming Violence: A Critical Theory of Genocide, Torture and Terrorism (Columbia University Press, 2018), Moralische Politik oder politische Moral? Eine Analyse aktueller Debatten zur internationalen Gerechtigkeit (Campus, 2008), and coeditor (with Mihaela Mihai) of On the Uses and Abuses of Political Apologies (Palgrave, 2014).

The author is grateful to the participants in workshops in Glasgow, Vienna, Edinburgh, Leuven and Norwich for their useful feedback. Special thanks are due to Toby Kelly, Alex Livingston, Mihaela Mihai, and Nicola Perugini for providing him with written comments on a first draft. Andy Hom and Claire Duncanson kindly helped during the final revision phase. The four reviewers for Perspectives on Politics offered detailed and generous comments, which greatly improved the article. Finally, he expresses his gratitude to associate editor Daniel O'Neill for providing supportive feedback throughout the review process.
Worse still, they are accused of muddled ethical reasoning, of being guilty of making self-contradictory claims that quickly crumble when subjected to serious scrutiny. Just war theorists, among others, charge pacifists with revering ideals of nonviolence that are both unworkable and in violation of principles of rights protection. Adhering to nonviolence might at first sight seem like a virtuous stance, but a complete renunciation of violence is ultimately irresponsible.

A powerful response to this charge has emerged in recent years. Countering the suspicion that pacifism is utopian, authors such as Dustin Howes (2009; 2013), Karuna Mantena (2012), and Todd May (2015) have insisted on another kind of pacifism: one that is credible, practical, and eminently realistic. Interestingly, these political theorists have based their defenses of pacifism on the findings of social scientists who have investigated the effectiveness of nonviolence in a number of empirical contexts. ${ }^{1}$

This article contributes to the debate between detractors and advocates of pacifism by developing a primer for defending pacifism on explicitly utopian grounds. Its main target is a particular way of critiquing pacifism, embodied most vividly by just war theory. A connected objective is to ask how the revitalization of pacifism along the lines of Howes, Mantena, and May could be complemented by a reflection on pacifism's utopian impulse. Envisaging pacifism as utopian is helpful, I argue, so long as this process is staged in a minor, rather than a major, key. In opposition to the mainstream picture of utopia, which unduly stresses the stifling perfection of a static end state, this minor type of utopia is uniquely suited for the vindication of pacifism because it 
foregrounds the real-world obstacles that any utopian project has to tackle.

Before I proceed, an important clarification on the article's theoretical apparatus is required. Because I propose a conceptual innovation that allows us to positively valorize pacifism as a utopian project, I take some liberty, interpreting the term "utopian" widely, and invite the reader to follow me in this hermeneutical exercise. When I maintain that critics have frequently labeled pacifism as utopian in a pejorative sense, I am reconstructing a general tendency shared across many, often divergent positions. Some authors explicitly refer to the term "utopia" to deplore pacifist initiatives (Orend 2013, 247); others, however, use notions such as "otherworldly" (Primoratz 2002, 221) or "unrealistic" (Sonderling 2012, 65) to condemn nonviolence.

Faced with this shifting terminology, this article aims to introduce some analytical clarity. My claim is that the concept of "utopia" describes a basic disposition that all the critiques (and even some defenses) of pacifism have in common, namely, an objection to the notion that war and violence can be overcome in the real world, simply by imagining a future in which peace would reign supreme. As we observe in the next section, this objection can be teased out in different ways and with the help of unique vocabularies; yet underneath the variegated formulations lies a deep and recurring discontent with the utopian dimension of pacifism. Accordingly, I subsume authors who do not overtly use the term "utopia" under this grouping so long as they express a functionally equivalent concern with pacifism as a form of wishful thinking.

My positive proposal entails that these critics misconstrue what is utopian about appeals to nonviolence. Peace should be viewed as a utopia of sorts; its pursuit presupposes envisioning a future that is very different from the world we currently inhabit. But anticipating that future does not necessarily imply that we are succumbing to the dangerous illusion of wishful thinking. Rather, nonviolence is utopian insofar as it strives to excavate emancipatory potentials that are latent in the status quo. Against the negative reading of utopianism, the idea is to pay close attention to the ways in which pacifism is enacted through concrete practices that draw on the utopian imagination.

The plan for the article is as follows: in the second section, I outline the standard case against pacifism and point toward various replies that have recently been contemplated. The next step (in the third section) detects a juncture in the midst of the utopian tradition between two competing strands: a major, afloat strand and a minor, grounded one. It is a mistake to collapse the latter into the former. The fourth section explores the minor, grounded version of utopianism through two illustrative examples relating to what I term prefigurative and testimonial pacifism. My particular interest lies with U.S. radical pacifist movements in the wake of World War II and with Amnesty International during its inital phase. The final section fleshes out some of the article's implications, casts a side look at anarchist politics, and probes the benefits of a utopian perspective for analyzing counterhegemonic movements.

\section{Pacifism and Just War Theory: A Family Constellation}

Pacifism is a multifaceted set of ideas and practices, spanning conversations over at least two millennia, that can be approached from two different angles (Cady 2010; Fiala 2004). The first approach focuses on the morality of using violence in general. Correspondingly, pacifism may denote an attitude of opposing all or at least most forms of violence in interpersonal, domestic, and international affairs. To put it inelegantly but accurately, on this account pacifism amounts to "nonviolentism" (Holmes 1991), the systematic renunciation of violence in all its guises. Whether pacifists reject violence in an absolute fashion or allow for exceptional situations in which violence can be justified (such as individual self-defense or defense of innocent others) is a question internal to this debate. Although only few authors subscribe to an unconditional form of pacifism qua nonviolentism, this is not an impossible position to hold. (Fox 2014)

The second way to characterize pacifists is by focusing on their narrower, yet still categorical, hostility to war instead of violence. This interpretation homes in on campaigns for a less violent world that endorse peace activism and nonviolent mobilization, for example. Duane Cady describes the position, which this type of pacifism rejects, as "warism" (2010, 17-30) or what we would normally call "militarism." On this perspective, pacifists are not necessarily dedicated to renouncing violence in the broader sense, but they do contest both the institution of war and the wider political, cultural, social, and economic system that entrenches war making (Cochran 1996).

Crucially, this second approach originates in an aversion to war as an activity with far-ranging consequences for the entire society: it is not only directed at specific wars with their particular justifications and rationales (Fiala 2014a; L. May 2015; Parkin 2018). Thus, the reason why pacifists qua "anti-warists" dispute a particular reason for going to war is not do with a peculiar feature of that war. Instead, their view of war is so comprehensively determined by a recognition of its devastating effects that any specific war has to be opposed. This opposition gives rise to a political rendition of pacifism (Alexandra 2003; Holmes 1999; 2015; Ryan 2015).

The bifurcation has led some to further separate pacifism from nonviolence (see, for example, Howes 
2013; Nepstad 2015b). Whereas pacifism is frequently associated with an ideological, spiritual, or philosophical stance, nonviolence is usually defined as a flexible tactic that groups deploy to attain certain goals. Following this line of reasoning, pacifism is perceived as an abstract worldview centered around a few unwavering convictions (nonviolentism or anti-militarism), whereas nonviolence comprises a diverse set of practices designed to sustain political action (Bharadwaj 1998). In contexts where pacifism underwrites nonviolent action, commentators speak of principled nonviolence. Parsing pacifism from nonviolence moreover implies that one can be a pacifist without resorting to nonviolence as a means of public protest; religious communities, such as the Amish, decide to remove themselves from wider society so they do not need to battle a social order that violates their sacrosanct ethics. Conversely, a group might be committed to nonviolent practices without accepting the ideological, spiritual, or philosophical underpinnings of pacifism at all. In this case, we speak of strategic nonviolence (Sharp 1970; 1990; 2013).

The conclusion revisits this distinction, contending that the shift in perspective argued for in this article also affects how the relationship between pacifism and nonviolence is conceived. But at this point, I want to consider why the label "utopian" has so often been attached to pacifists of all sorts. Although I primarily zoom in on just war theory, it is important to emphasize that pacifism has been attacked from multiple directions. Among the most influential ones are different types of realism ${ }^{2}$ and justifications of revolutionary violence. ${ }^{3}$ Authors as diverse as Reinhold Niebuhr, Hans Morgenthau, and Frantz Fanon have all expressed serious reservations about nonviolence's capacity to attain political ends.

In light of these manifold objections, my rationale for exclusively focusing on just war theory is straightforward: as a diverse tradition rooted within various cultural settings, just war thinking has been consistently geared toward refining a complex set of criteria to ascertain whether and under what conditions conflict would be permissible (Sorabji and Rodin 2006). Its rebuttal of pacifism appears to be so compelling because it is anchored in a sophisticated ethics of violence: today, just war thinking encompasses both historically oriented approaches, which couch the ethical reflection on war in terms of an ongoing dialogue between past and present ideas (O'Driscoll 2008; Reed and Ryall 2007; Rengger 2013), and analytical philosophical accounts, which seek to establish the veracity of their claims mainly through thought experiments (Frowe 2014; McMahan 2009). ${ }^{4}$ Although it might be an overstatement to proclaim that just war theory currently exerts a monopoly over the moral debate around war (Coates 2016, 20), it has certainly, due to its longue durée and its rich internal variety, mounted the most formidable challenge to pacifism.
Within just war theory, we can discern three key objections that feed into the indictment of utopianism. Following Fiala's taxonomy (2014b), I highlight pacifism's immorality, inconsistency, and impracticality. Elizabeth Anscombe (1961) famously surmised that pacifism is a problematic doctrine because of its failure to distinguish between innocent victims and guilty perpetrators of violence. In its absolute, rather than qualified, rejection of violence, pacifism qua nonviolentism indirectly licenses the slaughter of the innocent. The argument here is that pacifists are supposedly committed to protecting innocent life, but they fail to take seriously the moral and political imperative inherent in that commitment; it would be more appropriate, proponents of the just war doctrine such as Anscombe opine, to actively protect the rights of the innocent by violent means. What is more, she identifies pacifism with a general attitude of escapist withdrawal from the world, which infringes on the Christian duty of maturely engaging with evil. Trying to keep one's hands clean in an unjust world is a dishonest and futile posture.

Jan Narveson $(1965 ; 1968)$ constructs a closely related argument when he subjects pacifism to critical scrutiny. He claims that pacifism is theoretically incoherent because it fails to appropriately act to achieve the objective of holding human life sacred. On this view, pacifists are simply incapable of drawing the correct conclusions from their own premises: if the ultimate goal is to honor human life and to resist its destruction wherever it occurs, then pacifists must be prepared to take all the necessary steps for pursuing that goal. Pacifism is thus charged with being logically self-defeating.

The accusation of inconsistency leads directly to the final objection to pacifism, which is often voiced by advocates of radical politics, but has recently also been picked up in just war theory (Fabre 2012): it is simply unfit for the harsh realities bedeviling our contemporary condition. This view typically includes the proposition that nonviolence is an ideological standpoint that only the privileged can meaningfully defend. Polemically put, pacifism is a pathology (Churchill 1998) or a myth (Losurdo 2015), depriving oppressed people of the only resources by which they could actively resist their aggressors. On this account, pacifism serves the insidious purpose of sheltering those in power from oppositional force (Gelderloos 2007). A stubborn pledge of nonviolence undermines solidarity across counterhegemonic groups, which need to deploy a diversity of tactics (on this issue see Frazer 2016).

All these critiques riff on the theme that pacifism is insufficiently attuned to a world rampant with evil and injustice either by abdicating the imperative of engaging with wrongdoing, by declining to acknowledge the necessary implications of a pledge to safeguard the innocent, or by turning a blind eye to the fact of brutal 
oppression. Even though authors do not always explicitly refer to the term "utopia" when buttressing their preference for just war thinking, they base their ideas on arguments about pacifism's shortcomings that are functionally equivalent to the charge of utopianism.

To bring some order to this debate, we should therefore try to translate the three main objections to pacifism- its immorality, inconsistency, and impracticality-into the language of utopianism. Accordingly, pacifism is denounced as utopian insofar as it imagines a world in which all suffering is equal (the immorality charge); it is utopian insofar as it imagines a world in which the pursuit of justice is self-fulfilling (the inconsistency charge); and finally, it is utopian insofar as it imagines a world in which nonviolent resistance to oppression will always be successful (the impracticality charge). Behind the various objections lies a discontent with pacifism's aloofness and naivety: the vision of peace as a blueprint for a world without war and violence is simply unfit to guide real-world action.

Although it is true that just war theory, especially in its revisionist formulation (McMahan 2009; Rodin 2002), continues to thrive, we can currently also detect a reinvigoration of pacifist outlooks. The pushback has occurred along two tracks: positively, by rehabilitating pacifism and nonviolence as genuine options for political action, and negatively, by condemning just war theory's proclivity to degenerate into an exculpatory or legitimating discourse in the service of hegemonic actors. As I noted earlier, commentators have sought to render pacifism more credible, practical, and realistic by analyzing the panoply of feasible options that nonviolent actors have at their disposal when resisting oppressive regimes. This vindication attempts to present nonviolence as a worldly set of ideas and practices that are entirely compatible with a commitment to fighting evil and injustice (Cortright 2008, 334-39). This view is perhaps best conveyed in a passage from Dustin Howes:

Against the conventional wisdom, pragmatic pacifism maintains that the advocates of violence are prone to unrealistic ideological commitments that are often doomed to failure, whereas nonviolence offers a self-limiting, pragmatic, and realistic approach that accounts for the manifold difficulties of politics. In contrast to traditional pacifism, which rejects violence on moral grounds, this brand of pacifism relies upon political as opposed to moral principles to make the case against violence. Violence may be immoral, but recent empirical and theoretical work pushes us toward the perhaps more important insight that violence is counterproductive to politics. (Howes 2013, 428)

In terms of the negative critique, observers have highlighted the unpalatable effects of just war theory, particularly making imperial efforts more tolerable to increasingly war-weary audiences. Despite its ambition to subject all wars to normative scrutiny, just war theory has hence been attacked for its tendency to proffer all too facile excuses for warmongers. ${ }^{5}$ Proponents of just war theory are insufficiently sensitive to the true horror of war; all they do is deliver handy rationalizations for a domestic audience that needs to be charmed into its acceptance by the veneer of morality (Butler 2012; Fiala 2008; Neu 2017).

Maja Zehfuss has pushed this argument to its logical conclusion by claiming that "just war thinking ...plays a crucial role in setting up key ways of conceptualizing the problem which make it possible to believe that we are doing the right thing because we follow our best intentions" $(2018,34)$. Her critique suggests that the ideal of an "ethical war," which is pivotal to today's politics in a liberal vein, is founded on a reprehensible delusion that can only be upheld through the ideological scaffolding of just war theory. According to this account, pacifism has been deliberately discredited, not least by just war theory's success in dictating the terms of the debate about war and violence. The hope of these critics is that, once the notion of an "ethical war" is dismantled, new ways of reflecting about the global order will reveal themselves.

These two rejoinders erect safeguards against an uncritical embrace of just war theory. They remind us that, despite its ostensibly skeptical attitude, just war theory is always at risk of reproducing the systemic conditions in which violence is exercised. Although I do not wish to diminish their accomplishments, the recent recuperation of pacifism still strikes me as misguided in its presumption that, if just war theory's accusation of utopianism were indeed correct, then pacifism would turn out to be a problematic doctrine (Howes 2013, 437; King 2011). After all, the strategy of authors such as Howes, Mantena and May is precisely to establish, with the help of social science, that a commitment to nonviolence is not utopian at all: it does have positive real-world effects that war cannot engender.

However, this invective against utopianism cedes too much ground to just war thinking. My worry is that, by rendering pacifism more credible, practical, and realistic, these authors inadvertently reproduce and entrench the anti-utopian animus that the defenders of just war theory have been nurturing for a long time. By contrast, I demonstrate next that pacifism's utopian impulse is much more complex than either its detractors or advocates believe.

\section{Utopia, Split in the Middle}

Let us begin with an ecumenical framing of the utopian tradition. Ever since Thomas More coined the term in his eponymous novel in 1516, utopia has signified at the same time a no-place (ou-topos) and an Arcadian place (eutopos). The word play, oscillating between a simple absence and an alluring alternative, tells us something important about the functional structure of all kinds of utopia. As 
Paul Ricour perceptively notes with regard to the evocative image of a nowhere,

[A] place which exists in no real place, a ghost city; a river with no water; a prince with no people, and so on. What must be emphasized is the benefit of this special extraterritoriality. From this "no place" an exterior glance is cast on our reality. The field of the possible is now open beyond that of the actual; it is a field, therefore, for alternative ways of living. (Ricœur 1986, 16)

What this passage brings out is the procedural, rather than the substantive, aspect of utopian thinking. By opening up a field for "alternative ways of living," often through satire and hyperbole, utopias enable us to take a critical stance vis-à-vis the status quo. Varied forms of social organization shed new light on the situation in which readers find themselves.

Utopia's critical purchase is, of course, fully recognized in the literature, but it has often been interpreted as either a flight from reality or as a totalitarian plot for forcefully creating another world: the view from nowhere as the launchpad for radical upheaval. Utopias can become vehicles of domination insofar as the world, here and now, is shown to be utterly corrupt and in need of urgent repair. Numerous critics, including so-called Cold War liberals (see Müller 2008), have surmised that utopias are not only idle fantasies that might have distracting effects on their audience but may also become dangerous schemes for legitimizing social engineering on a large scale. Philosophers such as Karl Popper (2013), Isaiah Berlin (1997), and Judith Shklar $(1957 ; 1965)$ have seen utopias in a decidedly fatalistic way, with a primary objective of propping up totalitarian programs for transforming society in its entirety. On this perspective, the imaginary anticipation of a different world is itself perilous insofar as it seduces us to disregard the material sacrifices that would have to be made to attain a prosperous future. The suspicion that utopias represent a turning away from worldly affairs is a commonplace in the wider discussion in social and political theory.

Against these views, it is important to insist, however, that interpreting utopia as otherworldly and deluded hinges on an intellectual shortcut. Utopias entail ways of imagining "alternative ways of living" that do not necessarily coalesce into rigid templates for an Arcadian future. This point has recently been made in utopian studies. Several commentators, including Miguel Abensour (1999; 2008) and Russell Jacoby (2005), have identified a rupture within the utopian tradition itself: between a highly visible strand that seeks to conjure static visions of a world to come, devoid of change and contestation, and a more covert, yet equally noteworthy strand that draws on utopian thinking and acting so as to gain distance from the status quo.

The (Cold War) liberal critique of utopianism is prone to collapsing the second strand into the first one, such that all types of utopianism appear as harbingers of totalitarianism. This is a mistake that a subtler interpretation manages to avoid by referring to what Ruth Levitas (2013) calls "utopia as a method." Levitas is skeptical of endeavors to define utopia narrowly, for instance, by fixating on a particular literary genre or by placing utopianism primarily within the canon of political theory. Influenced by Ernst Bloch's magisterial The Principle of Hope (1995), Levitas prefers a conceptualization of utopia as the "expression of a desire for a better way of being" $(2011,9)$. She argues that a holistic reading of utopianism must cut across the divide between cognition and action. This implies that utopias not only engage the imagination by making up different worlds but also by shaping actual practices, in the here and now. Utopias, then, are as much about the way we think as they affect the way we act. As a consequence, the monolithic interpretation of utopianism is too restrictive, highlighting only one aspect of a rich kaleidoscope of ideas and practices that all qualify as utopian.

Using the split in the utopian tradition as a starting point, let us now outline minor, grounded utopias. Minor utopias - a term coined by Jay Winter (2006) in his historical sketch of peace initiatives during the twentieth century —embody cultural and social projects whose aim is the partial renewal of the world. In contrast with major utopias, which Winter associates with despotic reveries of social engineering, their telos is to become incubators of change on a local, rather than global, scale. Because they necessarily react to particular constellations of power, minor utopias reflect the material and ideological conditions from which they emerge. ${ }^{6}$ Winter probes this dialectical movement by tracing a fundamental tension within utopianism:

First, it [utopianism] is a narrative about discontinuity. It is a story through which men and women imagine a radical act of disjunction, enabling people, acting freely and in concert with others, to realize the creative potential imprisoned by the way we live now. But secondly, since the narrative is written by men and women rooted in contemporary conditions and language, it inevitably shows where they are, even as it describes where they want to be. Utopias force us to face the fact that we do not live there; we live here, and we cannot but use the language of the here and now in all our imaginings. (Winter 2006, 3)

Therefore, one way in which these minor utopias are constitutionally grounded is with regard to the contexts from which they try to escape: the "language of the here and now," in Winter's words, cannot be simply discarded like an old coat. Although utopias may appear unattached - consider how many early modern utopias are set on islands - they in fact remain tethered, often in surreptitious ways, to the material and symbolic universe that they reject (Jameson 2005, 170). Whereas major utopias obfuscate this tethering by attempting to altogether transcend the strictures of the present condition, minor 
utopias openly acknowledge the dialectics at play when experimenting with alternative ways of living. ${ }^{7}$

But utopias are grounded in another respect as well, via the everyday experiences of the people who are enacting utopian visions through practices of resistance and dissidence (Davis 2012). Instead of merely scrutinizing the abstract ideas behind political action, grounded utopianism describes how particular social milieus can be turned into spaces for emancipatory practices. Davina Cooper has recently examined utopias through the lens of quotidian encounters in settings designed to foster communal promise and hope; she defines these sites as everyday utopias,

networks and spaces that ...perform regular daily life in a radically different fashion. Everyday utopias don't focus on campaigning or advocacy. They don't place their energy on pressuring mainstream institutions to change, on winning votes, or on taking over dominant social structures. Rather they work by creating the change they wish to encounter, building and forging new ways of experiencing social and political life. (Cooper 2014, 2)

Far from being figments of the imagination, grounded utopias thus strive to actualize the utopian desire for change in the here and now. This feature drives them beyond the realm of cognitive processes into the sphere of contentious politics, albeit on a small scale. Although social transformation may be an ulterior ambition of minor, grounded utopias, their chief objective is to salvage, through "alternative ways of living," emancipatory potentials from within existing power structures. ${ }^{8}$

Viewed from this vantage point, it becomes clear why both detractors and advocates of nonviolence are too quick to dismiss pacifism's utopian impulse. If utopianism pertains to both imagination and action, then we can interpret at least some nonviolent movements and initiatives as utopian in a nonpejorative sense. Accordingly, a few authors have contended that pacifism and utopianism are bound up with one another. Tom Moylan, for example, proposes that Levitas's conception of utopia as a method can helpfully illuminate social movements. On this account, both principled pacifists and campaigners for strategic nonviolence resist oppression by embodying the change they want to see in the wider world: "In challenging oppositional violence and exemplifying alternative nonviolent manoeuvres, they function as a strategic or at least a tactical vanguard, as a utopian sensei or even a utopian 'commissar' whose methods are dialogical and not centralist" (Moylan 2015, 190).

Stellan Vinthagen surveys related terrain with his concept of "utopian enactment" (2015, 206-54). His suggestion, inspired by both Gandhi himself and the Gandhian philosopher Richard Gregg, is to scrutinize the efforts of activists in terms of dramatic performances that anticipate a peaceful future. When they refuse to use violence in their practice of resistance and refusal, they elect to suffer the painful consequences of violent repression. Yet, pace just war theory, this suffering is not a private decision to keep one's hands clean, but fulfills a demonstrative function by "trying through ... 'as if actions to apply the nonviolent future in the present, precisely where this is most difficult, near violence and oppression" (Vinthagen 2015, 253, emphasis in the original).

In sum, the notion of minor, grounded utopia deviates along two axes from the standard picture of utopia. First, minor utopias are distinct from major utopias because of their acknowledgment of the limitations that the here and now imposes on the aspirations to build a better future. Second, grounded utopias differ from afloat utopias in that they link imaginative strivings to everyday practices. Taken together, these two features help us retrieve a meaning of utopianism that both the critics and the defenders of pacifism have thus far missed: an empowering vision for creating another world that works through the contradictions of the status quo, without succumbing to the dangerous illusion of wishful thinking. ${ }^{9}$

\section{Two Modes of Pacifist Utopianism: Prefiguration and Testimony}

We can further sketch the contours of peace as a minor, grounded utopia by concentrating on two of its enactive modes: prefiguration and testimony. Although they are related to each other, prefiguration and testimony are situated at the extreme opposite ends of a spectrum of activities that characterize pacifist utopianism. They set into motion different ways of performing, rather than merely speculating on, pacifism, moving back and forth between cognition and action, between contemplating and doing, and between the future and the present.

In the most general terms, we may describe prefiguration and testimony as follows. Prefigurative pacifism strives to promote nonviolence "as if" a world were already in existence where violence is utterly discredited as a means to attain political ends. Several authors have noted, with respect to recent social movements, that prefiguration serves various interconnected goals: by employing horizontal decision-making procedures, activists endeavor to "build the new society in the shell of the old." Such anticipatory action is intended to transmit a strong signal to society at large that its hegemonic order, in which democracy has been hollowed out, is utterly fraudulent (Boggs 1977; Kinna 2017; Leach 2013; Sande 2015; Yates 2015).

This communicative function is also central to testimonial pacifism (Martin and Varney 2003). Testimony is located at the other end of the spectrum: through the public witnessing of violence, a system of oppression is laid bare to wider society so as to provoke a shock that will move the audience into a peaceful future. Providing testimony is not the same as standing by in passivity. 
Peace witnesses hold up to society a mirror that is designed to reflect reality back on those who engage in violence and on bystanders who avert their eyes so they can remain unaffected by their surroundings (Hess and Martin 2006; Martin 2005). Crucially, even though "acting as if" and "bearing witness" appear like polar opposites, they share a vital feature: their orientation to a world of nonviolence supplies a critical tool for uncovering problems concealed within the status quo.

My goal here is to study in some detail whether the framework of minor, grounded utopianism, with its emphasis on working through the contradictions of the status quo, can be conducive for better understanding both "acting as if" and "bearing witness" as pacifist strategies. Let us now refine this abstract model by unpacking two examples, which operate through practices of prefiguration and testimony that exhibit the tenets I identify with minor, grounded utopianism. The purpose of this section is not to paint a fully comprehensive picture of prefigurative and testimonial enactments of pacifism, nor is it to glorify particular social movements and issue a stern judgment on others. Instead its aim is to demonstrate that the framework of minor, grounded utopianism can shed light on nonviolent activism, illuminating both its successes and its failures. That the inherent complexity of each case needs to be reduced for presentational reasons strikes me as inescapable.

In the first example, a number of radical pacifist movements, such as the Committee for Non-Violent Revolution, the Committee for Non-Violent Action, and the Peacemakers, sprang up in the United States in the late 1940s and early 1950s (Cortright 2008, 109-25). Any form of violent behavior during their protests was prohibited from the get-go; resistance was to be marshaled on strictly nonviolent grounds. Facing fierce opposition from the state and opprobrium from society, these groups sought to turn themselves into catalysts of transformation. Given the widespread patriotism in the immediate aftermath of World War II and the concomitant attrition of pacifist sentiments, their strategy involved the creation of small-scale cells that internally adhered to the kind of peace and democracy they wished to spread across society (Danielson 2015).

Like Gandhi, the radical pacifists maintained that nonviolence was ultimately more efficacious in prompting social transformation than violent resistance. Associating the pacifist calling with the underground activities of early Christians, A. J. Muste, a Dutch-born leader of the Peacemakers and vehement critic of the emerging doctrine of Cold War realpolitik (Danielson 2006), assessed the situation in rather bleak terms: "It seems altogether likely that building a radical pacifist movement of any size will be a tougher and slower job in the U.S. than anywhere else.... Will reaction prove so strong in the U.S. that we have to keep a small remnant alive ... a church in the catacombs pattern? (quoted in Polletta and Hoban 2016, 289).

It is essential to point out that these groups openly espoused the terminology of utopianism to explain and justify their politics. As Francesca Polletta observes, the radical pacifists believed that "an honest utopianism ... had to be a part of a radical politics worthy of the namebut a utopianism that refused to withdraw from the political world" $(2002,38)$. Their worldly engagement hence corresponds with the minor, grounded utopianism theorized earlier.

So how did the radical pacifists concretize their utopian project? The internal structure of these movements was based on egalitarian principles that were supposed to anticipate the nonoppressive order they were aiming to institute within society at large. The plan was precisely to prefigure in their actions the world they planned to bring about through canvassing and lobbying, hoping that the old shell would wither away once the new world was born within. However, their deep commitment to a nonhierarchical organization frequently came into conflict with their public mission of mobilizing for peace. The dilemma was clear: because these groups were politically and socially marginalized, they were compelled to turn inward to keep the momentum going and bolster the members' morale. At the same time, those who were affected by the message of nonviolence needed to be addressed in such a way that they immediately grasped the attractiveness of the alternative world imagined and enacted by pacifists.

This friction points to a dilemma pervading the collective identity of social movements (Della Porta and Diani 2006, chap. 4). The difficulty for activists facing an intensely adverse environment is how to persuasively speak to the people in the wider public without compromising the group's internal integrity or weakening their grip on the collective's foundational values. Although the radical pacifist groups in the late 1940s and early 1950s were not trying to become mass movements, they still struggled to negotiate the tension between an inward-looking consolidation of egalitarian ideals and an outward-looking strategy for advocacy. This tension became most palpable when their commitment to collaborative relationships negatively influenced external constituency building. As a consequence, their peculiar brand of pacifism made them vulnerable to strong leadership claims, which ran counter to self-professed benchmarks of nonhierarchical organization (Polletta 2002, 41-42).

In many respects, these groups' activities and initiatives were admirable. They bravely stood up against a political establishment and a societal mainstream that identified peace with cowardly appeasement; they experimented with ways of cooperating that intended to maximize inclusion and horizontality; they were fearless in their use of nonviolent forms of protest. Through their anticipation of 
a peaceful future, these groups performed a critical function in the postwar era (Danielson 2008). Later, they would have substantial impact on the civil rights agenda and especially on Martin Luther King Jr. ${ }^{10}$

Yet, the radical pacifists were also working through precisely those contradictions that permeated the wider public in the United States after World War II (and even today). The main fault lines in their activism ran along largely predictable divisions of gender and race. At the same time as they tried to abolish hierarchies within their ranks, the protagonists of these groups assumed, often unreflectively, a cultural homogeneity within their organizations: "When pacifists talked about democracy within their organizations, they meant among people with similar ideological commitments, formal education, and political expertise" (Polletta 2002, 43).

Although inclusion and horizontality were thus objectives of their prefigurative politics, the basis for who would get recognized was still shaped by the gendered and racialized matrices that structured the societal mainstream of that period. Women occupied especially uncertain positions within this utopian setting: they were openly valued as equal members in the struggle for peace, playing important roles in the radical pacifist groups, but their very presence also stretched the notion of universal "brotherhood" to its breaking point. In the words of another commentator,

The activism promoted by the radical pacifist movement was a highly gendered phenomenon that shaped the experience of women and men in different and unequal ways. Male activists actively promoted a definition of pacifist action that equated political militancy with a rough and rugged style of heroic manhood. In their hands, political protest became a way to defend and define their masculinity-a type of direct action identity politics disturbingly similar to that promoted by the culture of militarism, which identified self-sacrifice and courage as the primary markers of manly citizenship. (Mollin 2006, 3, see also Mollin 2009)

The unsure standing of African Americans resembled in some respects that of women. Although eradicating racial segregation was one of the key targets of groups such as the Congress for Racial Equality (CORE) which orchestrated, for example, the so-called Journey of Reconciliation in 1947, a two-week bus ride through southern states governed by Jim Crow laws (Catsam 2009) - the results of these campaigns must be deemed mixed at best. Albeit an interracial group from the start, CORE's leadership was mostly white and exclusively male, "committed to a race-blind 'brotherhood of man', but not yet sure of how to make concrete contributions to the black freedom struggle" (Mollin 2004, 122).

Even though we must not overlook the contributions of alternative peace initiatives run by black women (McDuffie 2011), the most influential groups in the wake of World War II clearly failed to relinquish the racial divide they were attempting to abolish in society at large. The political language of universalism underpinning their pacifist agenda, apparent in the color-blind invocation of an all-encompassing "brotherhood," made a genuine alliance with those resisting the oppression directed at African Americans almost impossible. It would take the civil rights movement, more than a decade later, to rearticulate universalism in such a way that the struggle for black freedom could finally gain traction (Hall 2005).

My second example concerns one of the most prominent NGOs today, Amnesty International, particularly its early years at the beginning of the Cold War. The focus is on Amnesty's foundational principle of bearing witness to human suffering, which is also central to other human rights NGOs, such as Médecins sans Frontières (Doctors without Borders; Redfield 2013).

Although Amnesty is usually not considered a pacifist organization, an unconditional pledge to nonviolence featured prominently in its historical development. This becomes especially apparent when we look at a public figure whom Amnesty initially did not recognize as a prisoner of conscience: Nelson Mandela. Although Amnesty eventually offered him its "Ambassador of Conscience" award in 2006, in 1964 when he was sentenced to life in prison, Mandela's name was not included in its list of prisoners of conscience. The justification for this decision was Amnesty's erstwhile dismissal of any form of activism or policy that propagated violence, even when targeted at oppressive regimes (Clark 2001, 14; "Mandela to Get Conscience Award" 2006). As somebody who had openly encouraged violent resistance against the apartheid state, his suffering-although authentic and undeniable - was simply not deemed "unjust." Mandela's story thus speaks to the centrality of nonviolence within Amnesty's ethico-political universe.

To grasp the importance of this point requires some historical background. Amnesty was founded in 1961, by the British lawyer Peter Benenson, a converted Catholic of Russian Jewish descent (Buchanan 2002; 2004). Benenson's energy was channeled to prisoners of conscience, those subjected to state violence merely on the basis of their beliefs and convictions. The means that Amnesty employed in its activism, at least during its initial phase, were characterized by a detached objectivity in research and reporting. During the early 1960s, Benenson and those supporting his mission were adamant about the need to keep an equal distance from the Great Powers embroiled in the Cold War; Amnesty was supposed to operate on an "extrapolitical" platform, standing in solidarity with prisoners of conscience around the world, but without endorsing any particular creed or worldview. This constituted the normative basis for Amnesty's reliance on unbiased research into infringements on civil and political rights, seen as further consolidating its "moral position, that of the apolitical, neutral, impartial observer" (Hopgood 2009, 242). 
To comprehend the purpose of testimony in backing detainees, further historical context is needed. Bearing witness has always played an important role for pacifists, perhaps most famously in the Quaker movement (Ceadel 2014; Dandelion 2008; Smith 1996). The Quaker view holds that it is a Christian duty to oppose war in the broadest possible sense, and testimony is an important part of its strategy for resisting advocacy for and contributions to war. Amnesty's founders were heavily influenced by this religious coloring of pacifist activism. The pervasiveness of spiritual symbols also is seen in Amnesty's official logo, a burning candle surrounded by barbed wire (Lahusen 1996, 239)

Fashioning itself as a beacon of apolitical, neutral, and impartial objectivity in a turbulent sea of conflicting creeds and worldviews strengthened Amnesty's reputation over time, culminating in a sort of secular religion, in which it was seen as a quasi-spiritual organization, its doctrinal core held together by a deep faith in the sanctity of human rights. Stephen Hopgood, who introduced the phrase secular religion to portray Amnesty's institutional culture, grasps the basic dynamic succinctly:

Amnesty's lack of building blocks-its social and geographical separation from any specific national social class or group - created an initial detachment. Its growing symbolic role as a universal flame-bearer then edged it toward rules, procedures, and finally doctrine that maintained moral authority by elevating the idea of impartiality to an organizational imperative. It sought to construct in practical terms the kind of space-above, beyond, outside the world - in which the idea of objective morality of a kind of universal truth, could be anchored. (Hopgood 2006, 60)

The emphasis on carving out a space "above, beyond, outside the world" foregrounds the utopian aspirations of Amnesty's testimonial pacifism. Observing politics from such a transcendent position is premised on imagining an alternative world that looks radically different from the present moment. When peace witnesses faithfully record what is happening in the here and now, their evidence, preserved for future generations, performs a commemorative function. For testimony to call attention to structural wrongdoing, distance must be maintained between the observer and the observed, the activist and the sufferer. The epistemological status of truth-telling thus depends on researcher-activists protecting their vantage points from undue distortions and biases. Amnesty's reports therefore resemble investigative journalism or, indeed, academic inquiry in that the singular norm governing them is the falsifiable truth of what is being conveyed. Its "interpretive capacity" (Clark 2001, 16-18) relies on giving an accurate and perspicuous account of frequently inchoate patterns of human rights violations.

The celebration of detachment and objectivity has repercussions for how the suffering subject is represented. If testimony is to generate the desired effect of garnering public support, human suffering needs to be depicted in a clear-cut way that leaves little room for doubt about perpetrators and bystanders. The victim's absolute innocence is key to the smooth operation of "humanitarian reason" (Fassin 2012). Innocent life is thereby elevated to a sacralized status, for instance, through the many images of children and women in Amnesty's reports, which are meant to elicit visceral responses from the audience. Call this the totemic dimension embedded within the human rights imaginary (Hopgood 2013, 69-72).

A difficulty posed by this model of impartiality arises from the way Amnesty's core mission is simultaneously facilitated and constrained by the guiding principle of truth-telling. The predicament appears to be this: for testimony to lead to positive results, detachment must not feel like cold-hearted indifference, dispassionate distance to the suffering subject must not evoke a sense of isolationism, and the observational stance must not eclipse the activist's moral outrage. Later on, especially during the genocide in Rwanda, the tension stemming from the very idea of testimony would cause a severe crisis in Amnesty's "ethos-in-action" (Hopgood 2006, 76); this crisis has arguably been exacerbated during recent wars in the Middle East.

These two cases tell us something about the appeal of prefiguration and testimony as modes of pacifist utopianism. Both "acting as if" a peaceful order is already in place and the method of "objectively" documenting human suffering spring from the desire for a different world. They unfold a space beyond the here and now within which prefigurative and testimonial practices can become effective. But this space, albeit utopian in essence, is not the product of wishful thinking. Prefigurative and testimonial actions are deeply embedded in the world as we know it; they occupy ambiguous sites, rife with conflict and contestation.

What is distinctive about both kinds of utopian pacifism is that they deliberately confound, albeit in different ways, the trajectory leading from the present moment's violence to an uncertain future. The feminist activist and scholar Elise Boulding has dealt with this issue through her pioneering work on the human capacity to produce images of concrete alternatives to war. ${ }^{11}$ Such future-oriented visions can galvanize struggles in the here and now by debunking the potent myth that making war is simply humanity's destiny. Other feminist thinkers have pursued similar lines of reasoning, stressing that pacifism aims to "construct an alternative to war by addressing the conditions that make it seem that war is the default mechanism for securing justice" (Hutchings 2018, 185; see also Frazer and Hutchings 2014; Ruddick 1989). Importantly, this utopian mode of thinking about alternatives should not be mistaken for a predictive method: its main purpose is to inspire change in the face of massive obstacles, not to forecast what the future will eventually bring. 
What makes both the radical pacifists in the aftermath of World War II and Amnesty International minor, grounded utopias is their inability to escape the predicaments they attempt to resolve. They envisage nonviolence as a viable and indispensable alternative to the status quo; nonetheless, in their quotidian encounters, they also remain mired in the "very contradictions they seek to supersede" (Winter 2006, 7). Their worldly orientation goes hand in hand with a rejection of what I have earlier called major and afloat utopianism: the search for a static blueprint that knows no dispute or transformation.

For the radical pacifist groups in the late 1940s and early 1950s, the continued prevalence of male white leadership threw into sharp relief the limitations that the language of universal "brotherhood" imposed on their institutional culture and decision-making procedures. Although inclusion and horizontality were officially celebrated, the boundaries of equality were drawn along culturally dominant coordinates, with the effect that minorities could not occupy leadership positions. Consequently, outsiders within the organization, especially women and African Americans, remained largely disempowered.

The case of testimonial pacifism relates a different story. Although human rights have been called the "last utopia" (Moyn 2010)—a morally pure counterpoint to a world ravaged by dangerously divisive ideals - an investigation of Amnesty's pledge of impartiality opens up another perspective. Bearing witness involves an ethos that is predicated on extrapolitical truth-telling. This is the essence of its "self-imposed limited mandate" (Baehr 1994). Yet, in reality the imperative of enunciating in public nothing but the truth runs the risk of appearing overly anemic, menacing the core mission of an activist NGO that strives to make the world a better place. ${ }^{12}$ Caught in the gulf between the epistemic demands of truth-as-testimony and the duty to positively intervene to alleviate human suffering marks out Amnesty as a minor, grounded utopia. Amnesty intends to speak from a place beyond politics, but the reality of human suffering, "unjust" or otherwise, necessarily forces them back to the ground of compromise and concession.

\section{Fail Again, Fail Better}

What wider lessons can we learn from these examples of prefiguration and testimony? My proposal in this concluding section is that envisaging pacifism as a utopian project helps us appreciate why social movements and NGOs engaged in nonviolent struggles often seem to falter or at least fall short of the aspirations they set themselves. One consequence of what I have claimed so far is that, when debating nonviolent initiatives, we should refrain from tracing their shortcomings back to pacifism's intrinsic immorality, inconsistency, and im- practicality. Just war theorists of different stripes have pursued this denunciatory scheme without seriously considering whether a more differentiated account of utopianism would weaken the critical thrust of their objections. Insofar as utopian pacifism remains bound by the conventions it aims to transcend, what we perceive as failure should be more appropriately comprehended as an upshot of the complex negotiations between the strictures of the contemporary condition and the promise of an anticipated future (Jameson 2000). To paraphrase Samuel Beckett, failing again, but next time better, might hence be a suitable motto for this kind of pacifism. ${ }^{13}$

Here, a side look at anarchist politics can illuminate the advantages of the framework delineated in this article. ${ }^{14}$ In David Graeber's (2013) apologia for the Occupy Movement, we discover an instructive account of why the actual accomplishments of anarchist politics are often met with silence in the public sphere. Against the predominant view that the pacifist protests of 1968, for example, were a complete disaster in terms of tangible policy impact, Graeber insists that many of the demands put forth by the antiwar movement had delayed ramifications that can still be felt today. ${ }^{15}$ Graeber condenses this view in the following words: "Clearly, an antiwar movement in the 1960s that is still tying the hands of U.S. military planners in 2012 can hardly be considered a failure. But it raises an intriguing question: what happens when the creation of that sense of failure, of the complete ineffectiveness of political action against the system, becomes the chief objective of those in power?" (Graeber 2013, 278).

This last sentence reveals a tantalizing prospect: that the depiction of pacifism as pejoratively utopian serves specific interests, most notably the preemptive condemnation of nonviolence as immoral, inconsistent, and impractical. Viewed from this vantage point, a different set of responses to just war theory takes shape. Recall how just war theorists present their normative assessment of warfare as a more responsible reaction to a global constellation where evil and injustice cannot simply be wished away. Once we foreground the minor, grounded utopianism within pacifist movements and initiatives, just war theory loses at least some of its compelling character. For we can now grant that utopian thinking and acting are not always capable of comprehensively resolving all the contradictions of the status quo. Indeed, following Winter's and Cooper's reflections, we might conclude that minor, grounded utopias are by default contentious and imperfect; they are bound to be assembled within the force field of extant power structures.

This admission has repercussions for how we conceive of counterhegemonic campaigns more broadly. Naturally, the fact that women and African Americans could not obtain leadership posts within radical pacifist groups such as CORE or Peacemakers should make us skeptical of 
their progressive agenda; equally, the fact that peace testimony can, and often does, lead to a complacent retreat from the world must be a cause for concern to all those who want human rights to become tools of emancipation. Nonetheless, viewed through the framework of minor, grounded utopias, both issues are symptomatic of the ways in which prefiguration and testimony function as incubators of real-world change. The creators and inhabitants of minor, grounded utopias seek to distance themselves from the status quo through complex ways of anticipating alternative futures; yet they inevitably remain entangled in the contradictions that they aspire to resolve.

Espousing the maxim of "failing better" thus entails that we perceive both the successes and the failures of pacifist projects as temporary stations on a continuous, yet rocky journey. Trying to imagine and occupy utopian spaces is an experimental endeavor, full of promises and disappointments. Although it would be inaccurate to depict this journey as a linear, steady learning process, prefigurative and testimonial practices do possess an iterative dimension that enables nonviolent actors to gain awareness of the pitfalls of inaugurating real-world change. The perspective of minor, grounded utopianism then allows us to judge their performance in a nuanced manner, which is not only sensitive to their shortcomings but also appreciative of their accomplishments.

This observation casts light on the distinction between pacifism and nonviolence that we encountered earlier. Against the current tendency to pit them against one another, my analysis indicates that the contrast between principle and strategy is less stark than often assumed. Although it is, of course, correct that "those who engage in nonviolent action hold a variety of different beliefs, one of which may be pacifism" (Schock 2003, 705), it seems also apposite to point out how ideas and practices affect each other in minor, grounded utopias.

As we have seen, prefiguration and testimony inexorably alter the relationship between the means and the ends of political action. Rather than merely seeking to determine the most appropriate means for achieving their chosen ends, proponents of minor, grounded utopias contest the very notion that we can neatly separate means from ends. As a consequence, it will in concrete moments perhaps be possible to hold apart pacifism as an ideological, spiritual, or philosophical stance and nonviolence as a means-oriented tactic; however, the benefits of differentiating between pacifism and nonviolence are not always clear in cases such as the ones discussed in this article. Without denying the potential value of the distinction in other contexts, I therefore suggest that, within minor, grounded utopias, pacifist principles and nonviolent strategies are inextricably bound up with one another, to an extent that trying to unravel them can seem like a pointless exercise.
The significance of adopting this perspective for contemporary politics, beyond the two cases discussed here, is considerable. In underscoring the utopian impulses in social movements and initiatives, we are able to overcome a simplistic framework whereby the tensions resulting from minor, grounded utopias are taken to be intractable. To explain this further, I gesture toward just one example that discloses the broader potential of my proposal. Although the article's conclusion cannot be the place to unpack this multifaceted project in any kind of detail, consider for a moment the Black Lives Matter movement (Lebron 2017). One fruitful approach for making sense of its antiracist resistance is, in Melvin Rogers's words, to view it as a "utopian ... exercise of our moral imagination, struggling to be realized in practice" (Rogers 2016). Its commitment to a "pragmatic utopianism" (Dawson 2013, 194-200), which inventively combines bearing witness to state violence and the anticipation of a less oppressive future, exposes one of the many parallels between Black Lives Matter and the wider tradition of black radicalism (Bailey and Leonard 2015; Kelley 2002). Looking at this movement through the prism of a minor, grounded utopia lets us appreciate its freedom struggle, despite its many setbacks and uncertain future, as a dynamic form of social dreaming (Taylor 2016).

Finally, we can also ponder how my case for bolstering pacifism relates to earlier attempts to render pacifism more credible, practical, and realistic. As should be evident, I do not believe that conceiving of pacifism as utopian is at odds with these proposals. In the critique of just war theory, my article thus joins up with the ambitions of Dustin Howes, Karuna Mantena, and Todd May to reorient the ethical reflection on violence. Like these authors, I, too, have sought to steer attention toward enactments of pacifism that try to exert a positive impact on the world as we know it. But this article has also claimed that a vital aspect of nonviolence gets lost if we conceive it primarily as a means-oriented technique in the arsenal of contentious politics. There is something positively utopian about pacifism, which even its defenders habitually ignore. Grasping this aspect, in all its complexity, is a precondition for analytically understanding, normatively vindicating, and actively encouraging struggles for a nonviolent future.

\section{Notes}

1 The strength of their rejoinders therefore rests, at least to a certain degree, on large- $\mathrm{N}$ quantitative analyses confirming the efficacy of nonviolent forms of protest and resistance. See, for example, Chenoweth and Schock 2015; Chenoweth and Stephan 2011; Lawson 2015; Martin 2015; Nepstad 2011; 2015a; and White et al. 2015 . 
2 The term "realism" here covers a great variety of positions within political theory and international relations. These range from a Christian type of realism, perhaps most famously embodied by Reinhold Niebuhr (see Lovin 1995; 2008; Patterson 2008) to more political types, emblematically expressed through the work of Hans Morgenthau (see Scheuerman 2009; Williams 2007). What unites these positions is the notion that pacifism disregards the importance of power relations and stable orders in both domestic and international politics. On the complexity of realism, cutting across political theory and international relations, see representatively McQueen 2018; Sleat 2013.

3 The most famous discussion of revolutionary violence in the second half of the twentieth century stems from Frantz Fanon 2004. Fanon's argument is, in a nutshell, that the process of decolonization relies on a revolutionary politics that manages to transform the settler-colonial world through reactive and redemptive violence. Note, however, that his critique of nonviolence as bourgeois entitlement is much subtler than the widely held perception of Fanon as a prophet of ruthless vengeance intimates. See Frazer and Hutchings 2008; Kawash 1999; Tronto 2004.

4 On these two strands within just war thinking, see Braun 2018; Lazar 2017; O’Driscoll 2013.

5 This suspicion has a long history: Immanuel Kant $(2006,79)$ denounced the founding fathers of modern just war theory, Hugo Grotius, Samuel Pufendorf, and Emer de Vattel, as “tiresome comforters." See Williams 2012.

6 Winter's terminology resonates with Elise Boulding's comparison between micro- and macrolevel utopias. See Boulding 1986.

7 Regarding this aspect, Jameson's discussion of utopia's "spatial closure" is insightful. See Jameson 1982, 15455.

8 This view is also pivotal for Erik Olin Wright's longterm project of examining "real utopias." See Wright 2010; 2013. Another expression of this thought, which remains much more speculative than Wright's, can be found in John Rawls's late work (1999, 7, 1112) On Rawls, see Arnsperger 2006 and Böker 2017.

9 In that respect, the perspective of minor, grounded utopianism resonates with recent attempts to revisit the linkages between realist political theory and utopianism. See Geuss 2015; McKean 2016; Raekstad 2018.

10 For a description of the civil rights movement as an exemplar of grounded utopianism see Shor 2004.

11 For a selection of her writings see Boulding 2017. Boulding's research into processes of social transformation has had tangible impact on the fields of future and peace studies. See Hutchinson and Milojević 2012.
12 This point also raises some hard questions about Amnesty's neutrality and whether its equidistance is perhaps just a façade behind which ideological support for a liberal creed or worldview remains hidden. See Mutua 2001.

13 "All of old. Nothing else ever. Ever tried. Ever failed. No matter. Try again. Fail again. Fail better" (Beckett 1989, 101). Lucy Sargisson $(2014,243)$ also finds Beckett's dictum beneficial for capturing utopianism's impetus.

14 See Franks 2006. Although I do not explore the deeper links between anarchism and pacifism in this article, it is worthwhile to gesture to the vibrant debate around anarcho-pacifism, which rehearses many of the themes that I capture through the lens of utopianism. See Llewellyn 2018; Moses 2018.

15 Although it is true that the U.S. retreat from Vietnam was not immediately precipitated by the protests, the "Vietnam syndrome" - the widespread distaste for futile interventionism abroad-inhibited U.S. foreign policy for almost three decades to come. See Herring 2011.

\section{References}

Abensour, Miguel. 1999. "William Morris: The Politics of Romance." In Revolutionary Romanticism: A Drunken Boat Anthology, ed. Max Blechman, 126-61. San Francisco: City Lights Books. 2008. "Persistent Utopia." Constellations 15(3): 406-21.

Alexandra, Andrew. 2003. "Political Pacifism." Social Theory and Practice 29(4): 589-606.

Anscombe, G. E. M. 1961. "War and Murder." In Nuclear Weapons: A Catholic Response, ed. Walter Stein, 44-52. London: Burns \& Oates.

Arnsperger, Christian. 2006. "What Is Utopian about the Realistic Utopia? Relocating Rawls in the Space of Normative Proposals." Revue Internationale de Philosophie 237(3): 285-300.

Baehr, Peter R. 1994. "Amnesty International and Its SelfImposed Limited Mandate." Netherlands Quarterly of Human Rights 12: 5-22.

Bailey, Julius and David J. Leonard. 2015. "Black Lives Matter: Post-Nihilistic Freedom Dreams." Journal of Contemporary Rhetoric 5(3/4): 67-77.

Beckett, Samuel. 1989. Nohow On: Three Novels. London: John Calder.

Berlin, Isaiah. 1997. "The Pursuit of the Ideal." In The Proper Study of Mankind: An Anthology of Essays, eds. Henry Hardy and Roger Hausheer, 1-16. London: Chatto \& Windus.

Bharadwaj, L. K. 1998. "Principled versus Pragmatic Nonviolence." Peace Review 10(1): 79-81.

Bloch, Ernst. 1995. The Principle of Hope, Vol. 2. Cambridge, MA: MIT Press. 
Boggs, Carl. 1977. "Marxism, Prefigurative Communism and the Problem of Workers' Control." Radical America 11(6): 99-122.

Böker, Marit. 2017. "The Concept of Realistic Utopia: Ideal Theory as Critique." Constellations 24(1): 89-100.

Boulding, Elise. 1986. "Utopianism: Problems and Issues in Planning for a Peaceful Society." Alternatives 11(3): 345-66.

Boulding, J. Russell, ed. 2017. Elise Boulding: Writings on Peace Research, Peacemaking, and the Future. Cham, Switzerland: Springer International.

Braun, Christian Nikolaus. 2018. "The Historical Approach and the "War of Ethics within the Ethics of War." Journal of International Political Theory 14(3): 349-66.

Buchanan, Tom. 2002. “The Truth Will Set You Free': The Making of Amnesty International." Journal of Contemporary History 37(4): 575-97. . 2004. "Amnesty International in Crisis, 1966-7." Twentieth Century British History 15(3): 267-89.

Butler, Michael J. 2012. Selling a "Just" War: Framing, Legitimacy, and US Military Intervention. Houndmills, UK: Palgrave Macmillan.

Cady, Duane L. 2010. From Warism to Pacifism: A Moral Continuum. 2nd ed. Philadelphia: Temple University Press.

Catsam, Derek. 2009. Freedom's Main Line: The Journey of Reconciliation and the Freedom Rides. Lexington: University Press of Kentucky.

Ceadel, Martin. 2014. "The Quaker Peace Testimony and Its Contribution to the British Peace Movement: An Overview." Quaker Studies 7(1): 9-29.

Chenoweth, Erica and Kurt Schock. 2015. "Do Contemporaneous Armed Challenges Affect the Outcomes of Mass Nonviolent Campaigns?" Mobilization: An International Quarterly 20(4): 427-51.

Chenoweth, Erica and Maria J. Stephan. 2011. Why Civil Resistance Works: The Strategic Logic of Nonviolent Conflict. New York: Columbia University Press.

Churchill, Ward. 1998. Pacifism as Pathology: Reflections on the Role of Armed Struggle in North America. Winnipeg, Canada: Arbeiter Ring.

Clark, Ann Marie. 2001. Diplomacy of Conscience: Amnesty International and Changing Human Rights Norms. Princeton, NJ: Princeton University Press.

Coates, A. J. 2016. The Ethics of War. 2nd ed. Manchester: Manchester University Press.

Cochran, David Carroll. 1996. "War-Pacifism." Social Theory and Practice 22(2): 161-80.

Cooper, Davina. 2014. Everyday Utopias: The Conceptual Life of Promising Spaces. Durham, NC: Duke University Press.

Cortright, David. 2008. Peace: A History of Movements and Ideas. Cambridge: Cambridge University Press.
Dandelion, Pink. 2008. The Quakers: A Very Short Introduction. Oxford: Oxford University Press.

Danielson, Leilah. 2006. "Christianity, Dissent, and the Cold War: A. J. Muste's Challenge to Realism and U.S. Empire." Diplomatic History 30(4): 645-69.

. 2008. "It Is a Day of Judgment': The Peacemakers, Religion, and Radicalism in Cold War America." Religion and American Culture: A Journal of Interpretation 18(2): 215-48.

2015. “The Peace Movement since 1945.” In Oxford Research Encyclopedias: American History, ed. John Butler. http://americanhistory.oxfordre.com/ view/10.1093/acrefore/9780199329175.001.0001/ acrefore-9780199329175-e-71.

Davis, Laurence. 2012. "History, Politics, and Utopia: Toward a Synthesis of Social Theory and Practice." In Existential Utopia: New Perspectives on Utopian Thought, eds. Patricia I. Vieira and Michael Marder, 127-39. New York: Continuum.

Dawson, Michael C. 2013. Blacks in and out of the Left. Cambridge, MA: Harvard University Press.

Della Porta, Donatella and Mario Diani. 2006. Social Movements: An Introduction. 2nd ed. Malden, MA: Blackwell.

Fabre, Cécile. 2012. Cosmopolitan War. Oxford: Oxford University Press.

Fanon, Frantz. 2004. The Wretched of the Earth. New York: Grove Press.

Fassin, Didier. 2012. Humanitarian Reason: A Moral History of the Present. Berkeley: University of California Press.

Fiala, Andrew. 2004. Practical Pacifism. New York: Algora.

- 2008. The Just War Myth: The Moral Illusions of War. Lanham, MD: Rowman \& Littlefield.

_. 2014a. "Contingent Pacifism and Contingently Pacifist Conclusions." Journal of Social Philosophy 45(4): 463-77.

. 2014b. "Pacifism." In The Stanford Encyclopedia of Philosophy, ed. Edward N. Zalta. http://plato.stanford. edu/archives/win2014/entries/pacifism/.

Fox, Michael Allen. 2014. Understanding Peace: A Comprehensive Introduction. London: Routledge.

Franks, Benjamin. 2006. Rebel Alliances: The Means and Ends of Contemporary British Anarchisms. Edinburgh: AK Press.

Frazer, Elizabeth. 2016. "The Diversity of Tactics: Anarchism and Political Power." European Journal of Political Theory. https://doi.org/10.1177/1474885115627558.

Frazer, Elizabeth and Kimberly Hutchings. 2008. "On Politics and Violence: Arendt contra Fanon." Contemporary Political Theory 7(1): 90-108.

2014. "Revisiting Ruddick: Feminism, Pacifism and Non-Violence." Journal of International Political Theory 10(1): 109-24. 
Frowe, Helen. 2014. Defensive Killing. Oxford: Oxford University Press.

Gelderloos, Peter. 2007. How Nonviolence Protects the State. Cambridge, MA: South End Press.

Geuss, Raymond. 2015. "Realism and the Relativity of Judgement." International Relations 29(1): 3-22.

Graeber, David. 2013. The Democracy Project: A History, a Crisis, a Movement. New York: Spiegel \& Grau.

Hall, Jacquelyn Dowd. 2005. "The Long Civil Rights Movement and the Political Uses of the Past." Journal of American History 91(4): 1233-63.

Herring, George C. 2011. "The Vietnam Syndrome." In The Columbia History of the Vietnam War, ed. David L. Anderson, 409-29. New York: Columbia University Press.

Hess, David and Brian Martin. 2006. "Repression, Backfire, and the Theory of Transformative Events." Mobilization: An International Quarterly 11(2): 249-67.

Holmes, Robert L. 1991. "The Morality of Nonviolence." In Just War, Nonviolence and Nuclear Deterrence, eds. Duane L. Cady and Richard Werner, 131-48. Wakefield, VA: Longwood Academic. . 1999. "Pacifism for Nonpacifists." Journal of Social Philosophy 30(3): 387-400.

_. 2015. "The Metaethics of Pacifism and Just War Theory." Philosophical Forum 46(1): 3-15.

Hopgood, Stephen. 2006. Keepers of the Flame: Understanding Amnesty International. Ithaca, NY: Cornell University Press.

2009. "Moral Authority, Modernity and the Politics of the Sacred." European Journal of International Relations 15(2): 229-55.

2013. The Endtimes of Human Rights. Ithaca, NY: Cornell University Press.

Howes, Dustin Ells. 2009. Toward a Credible Pacifism: Violence and the Possibilities of Politics. Albany: State University of New York Press.

2013. "The Failure of Pacifism and the Success of Nonviolence." Perspectives on Politics 11(2): 427-46.

Hutchings, Kimberly. 2018. "Pacifism Is Dirty: Towards an Ethico-Political Defence." Critical Studies on Security 6(2): 176-92.

Hutchinson, Francis P. and Ivana Milojević. 2012.

"Worlds without War: Reflections on Elise Boulding's Life, Work and Legacy as a Peace Educator, Feminist and Futurist." Journal of Peace Education 9(2): 151-68.

Jacoby, Russell. 2005. Picture Imperfect: Utopian Thought for an Anti-Utopian Age. New York: Columbia University Press.

Jameson, Fredric. 1982. "Progress versus Utopia; Or, Can We Imagine the Future?" Science Fiction Studies 9(2): 147-58.

2000. "Utopia and Failure." Politics and Culture

(2). https://politicsandculture.org/2010/08/10/utopiaand-failure-by-fredric-jameson- $2 /$.
2005. Archaeologies of the Future: The Desire Called Utopia and Other Science Fictions. New York: Verso.

Kant, Immanuel. 2006. Toward Perpetual Peace and Other Writings on Politics, Peace, and History. ed. Pauline Kleingeld. New Haven: Yale University Press.

Kawash, Samira. 1999. “Terrorists and Vampires: Fanon's Spectral Violence of Decolonization." In Frantz Fanon: Critical Perspectives, ed. Anthony C. Alessandrini, 23759. New York: Routledge.

Kelley, Robin D. G. 2002. Freedom Dreams: The Black Radical Imagination. Boston: Beacon Press.

King, Mary Elizabeth. 2011. "Gene Sharp Is No Utopian." Waging Nonviolence. https://wagingnonviolence.org/ feature/gene-sharp-is-no-utopian/.

Kinna, Ruth. 2017. "Utopianism and Prefiguration." In Political Uses of Utopia: New Marxist, Anarchist, and Radical Democratic Perspectives, eds. S. D. Chrostowska and James D. Ingram, 198-215. New York: Columbia University Press.

Lahusen, Christian. 1996. The Rhetoric of Moral Protest: Public Campaigns, Celebrity Endorsement, and Political Mobilization. Berlin: De Gruyter.

Lawson, George. 2015. "Revolution, Nonviolence, and the Arab Uprisings." Mobilization: An International Quarterly 20(4): 453-70.

Lazar, Seth. 2017. "Just War Theory: Revisionists versus Traditionalists." Annual Review of Political Science 20(1): 37-54.

Leach, Darcy K. 2013. "Prefigurative Politics." In The Wiley-Blackwell Encyclopedia of Social and Political Movements 3 (Pe-Z), eds. David A. Snow, Donatella della Porta, Bert Klandermans, and Doug McAdam, 1004-6. Chicester, UL: Wiley-Blackwell.

Lebron, Christopher J. 2017. The Making of Black Lives Matter: A Brief History of an Idea. New York: Oxford University Press.

Levitas, Ruth. 2011. The Concept of Utopia. student ed. Oxford: Peter Lang.

2013. Utopia as Method: The Imaginary Reconstruction of Society. Houndmills, UK: Palgrave Macmillan.

Llewellyn, Joseph. 2018. "Building Emancipatory Peace through Anarcho-Pacifism." Critical Studies on Security 6(2): 259-72.

Losurdo, Domenico. 2015. Non-Violence: A History beyond the Myth. Lanham, MD: Lexington Books.

Lovin, Robin W. 1995. Reinhold Niebuhr and Christian Realism. Cambridge: Cambridge University Press.

. 2008. Christian Realism and the New Realities. Cambridge: Cambridge University Press.

Mandela to Get Conscience Award.” 2006. BBC News. http://news.bbc.co.uk/1/hi/world/africa/5359892.stm.

Mantena, Karuna. 2012. "Another Realism: The Politics of Gandhian Nonviolence." American Political Science Review 106(2): 455-70. 
Martin, Brian. 2005. "How Nonviolence Works." borderlands 4(3). http://www.borderlands.net.au/ vol4no3_2005/martin_nonviol.htm. . 2015. "The Dynamics of Nonviolence Knowledge." Mobilization: An International Quarterly 20(4): 533-45.

Martin, Brian and Wendy Varney. 2003. "Nonviolence and Communication." Journal of Peace Research 40(2): 213-32.

May, Larry. 2015. Contingent Pacifism: Revisiting Just War Theory. Cambridge: Cambridge University Press.

May, Todd. 2015. Nonviolent Resistance: A Philosophical Introduction. Cambridge: Polity.

McDuffie, Erik S. 2011. Sojourning for Freedom: Black Women, American Communism, and the Making of Black Left Feminism. Durham, NC: Duke University Press.

McKean, Benjamin L. 2016. "What Makes a Utopia Inconvenient? On the Advantages and Disadvantages of a Realist Orientation to Politics." American Political Science Review 110(4): 876-88.

McMahan, Jeff. 2009. Killing in War. Oxford: Clarendon Press.

McQueen, Alison. 2018. Political Realism in Apocalyptic Times. Cambridge: Cambridge University Press.

Mollin, Marian. 2004. "The Limits of Egalitarianism: Radical Pacifism, Civil Rights, and the Journey of Reconciliation." Radical History Review 88(1): 112-38. 2006. Radical Pacifism in Modern America: Egalitarianism and Protest. Philadelphia: University of Pennsylvania Press.

. 2009. "Women's Struggles within the American Radical Pacifist Movement." History Compass 7(3): 1064-90.

Moses, Jeremy. 2018. "Anarchy, Pacifism and Realism: Building a Path to a Non-Violent International Law." Critical Studies on Security 6(2): 221-36.

Moylan, Tom. 2015. "'To Live Consciously Is to Sow the Whirlwind': Reflections on the Utopian Standpoint of Nonviolence." Utopian Studies 26(1): 183-202.

Moyn, Samuel. 2010. The Last Utopia: Human Rights in History. Cambridge, MA: Belknap Press of Harvard University Press.

Müller, Jan-Werner. 2008. "Fear and Freedom: On 'Cold War Liberalism.'” European Journal of Political Theory 7(1): 45-64.

Mutua, Makau. 2001. "Human Rights International NGOs: A Critical Evaluation." In NGOs and Human Rights: Promise and Performance, ed. Claude Emerson Welch, 151-63. Pennsylvania Studies in Human Rights. Philadelphia: University of Pennsylvania Press. Narveson, Jan. 1965. "Pacifism: A Philosophical Analysis." Ethics 75(4): 259-71.

1968. “Is Pacifism Consistent?" Ethics 78(2): 148-50.
Nepstad, Sharon Erickson. 2011. Nonviolent Revolutions: Civil Resistance in the Late 20th Century. Oxford: Oxford University Press.

- 2015a. "Nonviolent Resistance Research." Mobilization: An International Quarterly 20(4): 415-26. 2015b. Nonviolent Struggle: Theories, Strategies, and Dynamics. New York: Oxford University Press.

Neu, Michael. 2017. Just Liberal Violence: Sweatshops, Torture, War. London: Rowman \& Littlefield International.

O'Driscoll, Cian. 2008. The Renegotiation of the Just War Tradition and the Right to War in the Twenty-First Century. New York: Palgrave Macmillan. . 2013. "Divisions within the Ranks? The Just War Tradition and the Use and Abuse of History." Ethics \& International Affairs 27(1): 47-65.

Orend, Brian. 2013. The Morality of War. 2nd ed. Peterborough: Broadview Press.

Parkin, Nicholas. 2018. "Conditional and Contingent Pacifism: The Main Battlegrounds." Critical Studies on Security 6(2): 193-206.

Patterson, Eric, ed. 2008. Christianity and Power Politics Today: Christian Realism and Contemporary Political Dilemmas. New York: Palgrave Macmillan.

Polletta, Francesca. 2002. Freedom Is an Endless Meeting: Democracy in American Social Movements. Chicago: University of Chicago Press.

Polletta, Francesca and Katt Hoban. 2016. "Why Consensus?" Journal of Social and Political Psychology 4(1): 286-301.

Popper, Karl R. 2013. The Open Society and Its Enemies. Princeton, NJ: Princeton University Press.

Primoratz, Igor. 2002. "Michael Walzer's Just War Theory: Some Issues of Responsibility." Ethical Theory and Moral Practice 5(2): 221-43.

Raekstad, Paul. 2018. "Realism, Utopianism, and Radical Values." European Journal of Philosophy 26(1): 145-168.

Rawls, John. 1999. The Law of Peoples; with, The Idea of Public Reason Revisited. Cambridge, MA: Harvard University Press.

Redfield, Peter. 2013. Life in Crisis: The Ethical Journey of Doctors without Borders. Berkeley: University of California Press.

Reed, Charles and David Ryall, eds. 2007. The Price of Peace: Just War in the Twenty-First Century. Cambridge: Cambridge University Press.

Rengger, Nicholas. 2013. Just War and International Order: The Uncivil Condition in World Politics. Cambridge: Cambridge University Press.

Ricœur, Paul. 1986. Lectures on Ideology and Utopia. New York: Columbia University Press.

Rodin, David. 2002. War and Self-Defense. Oxford: Clarendon Press. 
Rogers, Melvin. 2016. "What Good Is History for African Americans?" Boston Review. http://bostonreview.net/ editors-picks-us/melvin-rogers-what-good-historyafrican-americans.

Ruddick, Sara. 1989. Maternal Thinking: Toward a Politics of Peace. Boston: Beacon Press.

Ryan, Cheyney. 2015. "Pacifism(s)." Philosophical Forum 46(1): 17-39.

Sande, Mathijs van de. 2015. "Fighting with Tools: Prefiguration and Radical Politics in the Twenty-First Century." Rethinking Marxism 27(2): 177-94.

Sargisson, Lucy. 2014. Fool's Gold? Utopianism in the TwentyFirst Century. Basingstoke, UK: Palgrave Macmillan.

Scheuerman, William E. 2009. Hans Morgenthau: Realism and Beyond. Cambridge: Polity Press.

Schock, Kurt. 2003. "Nonviolent Action and Its Misconceptions: Insights for Social Scientists." PS: Political Science \& Politics 36(4): 705-12.

Sharp, Gene. 1970. Exploring Nonviolent Alternatives. Boston: P. Sargent. 1990. The Role of Power in Nonviolent Struggle. Boston: Albert Einstein Institute. 2013. Self-Liberation: A Guide to Strategic Planning for Action to End a Dictatorship or Other Oppression. Boston: Albert Einstein Institute.

Shklar, Judith. 1957. After Utopia: The Decline of Political Faith. Princeton, NJ: Princeton University Press. 1965. "The Political Theory of Utopia: From Melancholy to Nostalgia." Daedalus 94(2): 367-81. Shor, Francis. 2004. "Utopian Aspirations in the Black Freedom Movement: SNCC and the Struggle for Civil Rights, 1960-1965." Utopian Studies 15(2): 173-89.

Sleat, Matt. 2013. Liberal Realism: A Realist Theory of Liberal Politics. Manchester: Manchester University Press.

Smith, Allen. 1996. "The Renewal Movement: The Peace Testimony and Modern Quakerism.” Quaker History 85(2): 1-23.
Sonderling, Stefan. 2012. "Eternal Peace of the Graveyard: The Language of Peace Discourse and the Construction of the Global Humanitarian Concentration Camp.” Communicatio 38(1): 64-83.

Sorabji, Richard and David Rodin, eds. 2006. The Ethics of War: Shared Problems in Different Traditions. Aldershot, UK: Ashgate.

Taylor, Keeanga-Yamahtta. 2016. From \#BlackLivesMatter to Black Liberation. Chicago: Haymarket Books.

Tronto, Joan. 2004. "Frantz Fanon." Contemporary Political Theory 3(3): 245-52.

Vinthagen, Stellan. 2015. A Theory of Nonviolent Action: How Civil Resistance Works. London: ZED Books.

White, Peter B., Dragana Vidovic, Belén González, Kristian Skrede Gleditsch, and David E. Cunningham. 2015. "Nonviolence as a Weapon of the Resourceful: From Claims to Tactics in Mobilization." Mobilization: An International Quarterly 20(4): 471-91.

Williams, Howard. 2012. Kant and the End of War: A Critique of Just War Theory. New York: Palgrave Macmillan.

Williams, Michael C., ed. 2007. Realism Reconsidered: The Legacy of Hans Morgenthau in International Relations. Oxford/: Oxford University Press.

Winter, Jay M. 2006. Dreams of Peace and Freedom: Utopian Moments in the Twentieth Century. New Haven: Yale University Press.

Wright, Erik Olin. 2010. Envisioning Real Utopias. London: Verso.

- 2013. "Transforming Capitalism through Real Utopias.” American Sociological Review 78(1): 1-25.

Yates, Luke. 2015. "Rethinking Prefiguration: Alternatives, Micropolitics and Goals in Social Movements." Social Movement Studies 14(1): 1-21.

Zehfuss, Maja. 2018. War and the Politics of Ethics. New York: Oxford University Press. 